Original article

\title{
Pengaruh penggunaan madu Sumbawa dan madu olahan berbagai konsentrasi terhadap kualitas spermatozoa epididimis domba setelah penyimpanan dalam refrigerator
}

\section{The effect of Sumbawa honey and processed honey on the quality of ram spermatozoa after storage in refrigerator}

\author{
Siti Diyani Ludfiyaningrum ${ }^{1}$, Sri Gustari²* \\ ${ }^{1}$ Mahasiswa, ${ }^{2}$ Departemen Reproduksi dan Obstetri, Fakultas Kedokteran Hewan \\ Universitas Gadjah Mada \\ * Penulis koresponden, e-mail: gustari_vet@ugm.ac.id \\ Open access under CC BY - SA license, Doi : 10.20473/ovz.v10i1.2021.1-6 \\ Received February 1 2021, Revised February 7 2021, Accepted February 102021 \\ Published online April 12021
}

\begin{abstract}
Artificial Insemination is used to conserve genetic resources. It is necessary to preserve spermatozoa in a certain diluent at certain temperature before artificial insemination. Information regarding the use of honey in the spermatozoa diluent is still less in number. This research aims to determine the effect of Sumbawa honey and processed honey in various concentrations on the quality of spermatozoa after storage in refrigerator. The main materials used were five ram testicles. Spermatozoa was collected from cauda epididymis by mincing and adding $5 \mathrm{ml}$ PBS. The sample were divided into 7 groups of treatment: 1\% Sumbawa honey, 2\% Sumbawa honey, 3\% Sumbawa honey, $1 \%$ processed honey, $2 \%$ processed honey, $3 \%$ processed honey, and control using 0.5 gram glucose in $100 \mathrm{ml}$ Tris diluent. The assessment was carried out microscopically including motility and viability. Data were analyzed statistically using one-way analysis of variance (Anova) on the SPSS statistics 16.0 program. The results showed no significant difference $(p>0.05)$ in the motility and viability of spermatozoa in all treatment of Sumbawa honey $(1 \%, 2 \%, 3 \%)$, processed honey $(1 \%$, $2 \%, 3 \%$ ), and control. The conclusion of this study is that honey in spermatozoa diluent has no effect on the quality of spermatozoa.
\end{abstract}

Keywords: epididymal spermatozoa, honey, sheep, spermatozoa diluent, spermatozoa quality

\section{PENDAHULUAN}

Adanya ancaman kepunahan pada satwa liar dan peningkatan permintaan produk peternakan membutuhkan adanya usaha untuk melestarikan sumber daya genetik. Secara umum terdapat pilihan yaitu konservasi in-situ, ex-situ, dan melalui kriopreservasi plasma nutfah (ex-situ). Kriopreservasi plasma nutfah telah dikembangkan khusus untuk populasi langka dan commercial breeds yang secara luas dapat dimanfaatkan (Hiemstra et al., 2006).

Inseminasi buatan menjadi salah satu cara dalam usaha meningkatkan populasi hewan dengan lebih efektif. Sebelum dilakukan inseminasi buatan diperlukan adanya sumber genetik yaitu spermatozoa yang telah disimpan dalam pengencer dengan suhu tertentu. Pemilihan jenis pengencer harus tepat untuk mengurangi kerusakan akibat proses pembekuan. Pengencer yang telah umum 
digunakan antara lain pengencer susu skim, susu segar, Tris, sitrat, laktosa, dan lain-lain. Terdapat pula beberapa pengencer komersial siap pakai seperti Laiciphpos, Biociphos plus, Biladyl, Triladyl, dan lain-lain (Surachman, 2006). Pengencer pada preservasi spermatozoa memerlukan adanya bahan-bahan yang mempunyai fungsi sebagai buffer, persediaan substrat energi, antibiotik, dan pemeliharaan tekanan osmotik (Noakes et al., 2009). Bahan lain yang dapat digunakan dalam bahan pengencer yaitu madu. Beberapa keunggulan madu yaitu dapat menjadi pengganti gula, sumber vitamin dan mineral umumnya vitamin C, kalsium, dan zat besi, sumber antioksidan yang dapat meminimalisir pengaruh buruk radikal bebas, dan mengandung zat antibiotik yang dapat mencegah pertumbuhan bakteri tertentu karena memproduksi enzim hydrogen peroksida (Nadhilla, 2014). Kandungan utama madu yaitu senyawa karbohidrat seperti gula fruktosa $(41 \%)$, glukosa (35\%), sukrosa $(1,9 \%)$, dan dekstrin karbohidrat (Bogdanov et al., 2008).

Indonesia memiliki banyak sekali jenis madu yang masing-masing memiliki kandungan bahan yang berbeda. Madu Sumbawa berasal dari pohon bidara yang menjadi tempat tinggal lebah hutan di Pulau Sumbawa. Madu tersebut menjadi salah satu madu terfavorit di Indonesia. Madu Sumbawa memiliki kadar air yang lebih sedikit dibanding dengan madu daerah lainnya di Indonesia (Mardhiati et al., 2020). Madu Sumbawa terbukti dapat menghambat pertumbuhan kuman Staphylococcus aureus (Zulhawa et al., 2014). Selain madu alami, madu kemasan telah familiar untuk digunakan oleh masyarakat dan beredar lebih banyak sekitar $10 \%$ di pasaran dibandingkan madu alami (Wineri et al., 2014). Madu kemasan yang ada di pasaran jarang mencantumkan kandungan beragam unsur yang menandakan madu tersebut asli (Saepudin et al., 2014). Madu kemasan telah melalui proses pembuatan dengan menambahkan air dan campuran lainnya agar volume menjadi lebih banyak, sehingga viskositas madu kemasan lebih rendah dibanding madu alami. Pengenceran pada madu kemasan membuat efek antibakteri tidak seoptimal madu alami karena madu yang mengalami pengenceran akan mudah menyebar pada agar bakteri dan menurunkan kadar gula dalam madu (Wineri et al., 2014).

Mengingat banyaknya manfaat madu dan kandungan gula alami yang dapat berfungsi sebagai energi metabolis secara seluler, penggunaan madu dalam media pengencer dalam proses preservasi telah menjadi perhatian para peneliti. Akan tetapi, informasi mengenai penggunaan madu dalam pengencer dalam rangka mempertahankan kualitas spermatozoa yang berasal dari epididymis domba masih perlu banyak dikaji. Oleh karena itu, penelitian ini mengkaji penggunaan madu dalam pengencer spermatozoa terhadap motilitas dan viabilitas spermatozoa epididymis yang disimpan pada suhu refrigerator.

\section{MATERI DAN METODE}

Bahan utama yang digunakan pada penelitian adalah 5 testis domba ekor tipis yang diperoleh dari tempat pemotongan domba. Kauda epididimis beserta testis domba diambil segera setelah hewan disembelih, selanjutnya dibawa ke laboratorium dalam wadah dan dijaga suhunya $37^{\circ} \mathrm{C}$. Pengambilan spermatozoa dilakukan dengan pemisahan epididimis dan vas deferens dari testis lalu ditambah PBS $5 \mathrm{ml}$ dan dilakukan pencincangan (mincing) setelah itu spermatozoa diambil menggunakan pipet. Spermatozoa yang diperoleh dari kauda epididimis diperiksa motilitas dan viabilitasnya kemudian dibagi menjadi tujuh kelompok, selanjutnya diberi pengencer berbeda. Pengencer kontrol (K) berisi 3,634 gram kristal tris (hydroxymethyl aminomethane), 0,5 gram kristal glukosa, 1,99 gram asam sitrat monohidrat, aquabides $100 \mathrm{ml}$, kuning telur 20\%, $6 \mathrm{ml}$ gliserol, dan $25 \mu \mathrm{g}$ antibiotik penstrep. Pengencer perlakuan adalah $\mathrm{K}$ namun tanpa glukosa ditambah dengan madu Sumbawa 1\% (MS1), 2\% (MS2), 3\% (MS3), dan madu olahan 1\% (MO1), 2\% (MO2), 3\% (MO3). Sampel yang diencerkan dengan perbandingan spermatozoa : pengencer yaitu 1: 10 segera diperiksa motilitas dan viabilitasnya. Pemeriksaan motilitas dengan cara menaruh spermatozoa pada object glass dan ditutup dengan deck glass lalu diamati dibawah 
mikroskop dengan perbesaran 40x10 sedangkan pemeriksaan viabilitas dengan cara pembuatan preparat apus dengan pengecatan menggunakan eosin nigrosin lalu diamati dengan mikroskop perbesaran 40x10 Selanjutnya setiap pengenceran disimpan dalam refrigerator. Pengukuran daya tahan spermatozoa dilakukan dengan pemeriksaan motilitas dan viabilitasnya pagi dan sore hari hingga nilai motilitasnya 0 $10 \%$. Analisis data spermatozoa meliputi motilitas dan viabilitas dilakukan menggunakan one-way Anova pada program SPSS 16.0. Motilitas dan viabilitas diukur melalui pengamatan visual dengan menggunakan bantuan mikroskop. Metode seperti yang disebutkan di atas dilakukan dengan pengulangan sebanyak 5 kali.

\section{HASIL}

\section{Motilitas Spermatozoa}

Hasil pemeriksaan motilitas spermatozoa domba pada penelitian ini menunjukkan rata-rata spermatozoa dapat bertahan pada jam ke-24 kecuali pada pengencer madu olahan $3 \%$ yang bertahan pada jam ke-16 (Tabel 1).

Tabel 1 Rerata persentase motilitas spermatozoa epididimis domba dalam berbagai bahan pengencer pada suhu refrigerator selama 72 jam penyimpanan.

\begin{tabular}{cccccccc}
\hline \multirow{2}{*}{ jam } & \multicolumn{7}{c}{ motilitas dalam pengencer (\%) } \\
\cline { 2 - 7 } & MS 1 & MS 2 & MS 3 & MO 1 & MO 2 & MO 3 & K \\
\hline 0 & $65,00 \pm 18,03$ & $65,00 \pm 18,03$ & $65,00 \pm 18,03$ & $65,00 \pm 18,03$ & $65,00 \pm 18,03$ & $65,00 \pm 18,03$ & $65,00 \pm 18,03$ \\
16 & $16,00 \pm 15,17$ & $19,00 \pm 7,42$ & $14,00 \pm 8,94$ & $24,00 \pm 12,94$ & $12,00 \pm 10,37$ & $7,00 \pm 4,47$ & $12,00 \pm 12,55$ \\
24 & $5,00 \pm 8,66$ & $9,00 \pm 8,94$ & $5,00 \pm 8,66$ & $14,00 \pm 9,62$ & $5,00 \pm 5,00$ & 0 & $3,00 \pm 4,47$ \\
40 & $1,00 \pm 2,24$ & $5,00 \pm 8,66$ & $2,00 \pm 4,47$ & $6,00 \pm 8,22$ & 0 & 0 & 0 \\
48 & 0 & $4,00 \pm 8,94$ & 0 & $2,00 \pm 2,74$ & 0 & 0 & 0 \\
64 & 0 & $2,00 \pm 4,47$ & 0 & 0 & 0 & 0 & 0 \\
72 & 0 & 0 & 0 & 0 & 0 & 0 & 0 \\
\hline
\end{tabular}

MS1 $=$ pengencer tris kuning telur + madu Sumbawa 1\%; MS2 $=$ pengencer tris kuning telur + madu Sumbawa 2\%; MS3= pengencer tris kuning telur + madu Sumbawa 3\%; MO1= pengencer tris kuning telur + madu olahan $1 \% ; \mathrm{MO} 2=$ pengencer tris kuning telur + madu olahan $2 \% ; \mathrm{MO} 3=$ pengencer tris kuning telur + madu olahan 3\%; $\mathrm{K}=$ pengencer tris kuning telur + glukosa (kontrol), jam ke-16, 24, 40 , dst. $=$ pengamatan setelah penyimpanan, jam ke-0 = pengamatan sebelum dibagi menjadi 7 kelompok; ulangan $=5$.

Hasil analisis statistik terhadap data dalam 24 jam menunjukkan bahwa pemeriksaan motilitas spermatozoa pada pengencer Sumbawa $1 \% 0,01$; Sumbawa 2\% 0,38; Sumbawa 3\% 0,01; olahan $1 \% 0,22$; olahan $2 \% 0,12$; olahan $3 \%$ 0,00 ; dan kontrol 0,05 sehingga menunjukkan data terdistribusi normal $(\mathrm{p}>0,05)$ pada pengencer madu Sumbawa 2\%, olahan $1 \%$, dan madu olahan $2 \%$ tetapi data tidak terdistribusi normal ( $p<0,05)$ pada pengencer madu Sumbawa $1 \%$, Sumbawa 3\%, olahan 3\%, dan kontrol. Berdasarkan hasil tersebut pengujian dilanjutkan menggunakan one-way Anova dan didapatkan nilai signifikansi 0,113 ( $\mathrm{p}>0,05)$ yang berarti tidak ada perbedaan yang signifikan pada motilitas spermatozoa pada setiap jenis pengencer.

\section{Viabilitas Spermatozoa}

Hasil pemeriksaan viabilitas spermatozoa domba pada penelitian ini menunjukkan rata-rata spermatozoa dapat bertahan pada jam ke-112 kecuali pada pengencer madu olahan $2 \%$ yang bertahan pada jam ke-96 (Tabel 2).

Hasil analisis statistik terhadap data viabilitas dalam 24 jam menunjukkan bahwa pemeriksaan viabilitas spermatozoa pada pengencer Sumbawa 1\% 0,07; Sumbawa 2\% 0,66 ; Sumbawa $3 \% 0,65$; olahan $1 \% 0,55$; olahan $2 \% 0,91$; olahan $3 \% 0,56$; dan kontrol 0,032 sehingga menunjukkan data terdistribusi normal 
( $\mathrm{p}>0,05)$ pada pengencer madu Sumbawa 1\%, Sumbawa 2\%, Sumbawa 3\%, olahan 1\%, olahan $2 \%$, dan olahan $3 \%$ sedangkan data tidak terdistribusi normal $(\mathrm{p}<0,05)$ pada pengencer kontrol. Berdasarkan hasil tersebut pengujian dilanjutkan menggunakan one-way Anova dan didapatkan hasil nilai signifikansi 0,713 (p
$>0,05)$ yang berarti tidak ada perbedaan yang signifikan pada viabilitas spermatozoa pada setiap jenis pengencer. Analisis statistik terhadap viabilitas spermatozoa juga dilakukan pada semua jam pengamatan dan hasilnya tidak menunjukkan adanya perbedaan nyata $(\mathrm{p}>0.05)$.

Tabel 2 Rerata persentase viabilitas spermatozoa epididimis domba dalam berbagai bahan pengencer pada suhu refrigerator selama 160 jam penyimpanan.

\begin{tabular}{cccccccc}
\hline \multirow{2}{*}{ jam } & \multicolumn{7}{c}{ viabilitas dalam pengencer $(\%)$} \\
\cline { 2 - 8 } & MS 1 & MS 2 & MS 3 & MO 1 & MO 2 & MO 3 & K \\
\hline 0 & $79,20 \pm 8,76$ & $79,20 \pm 8,76$ & $79,20 \pm 8,76$ & $79,20 \pm 8,76$ & $79,20 \pm 8,76$ & $79,20 \pm 8,76$ & $79,20 \pm 8,76$ \\
16 & $26,40 \pm 14,54$ & $30,40 \pm 11,72$ & $27,40 \pm 11,5$ & $31,60 \pm 15,8$ & $18,40 \pm 11,63$ & $21,60 \pm 12,6$ & $20,40 \pm 17,24$ \\
24 & $20,2 \pm 15,0$ & $21,80 \pm 14,06$ & $18,80 \pm 11,54$ & $25,00 \pm 15,6$ & $13,60 \pm 10,55$ & $16,40 \pm 8,3$ & $12,80 \pm 11,03$ \\
40 & $16,00 \pm 15,08$ & $18,00 \pm 14,54$ & $15,60 \pm 10,7$ & $18,00 \pm 14,77$ & $10,40 \pm 9,07$ & $11,00 \pm 8,25$ & $10,00 \pm 12,30$ \\
48 & $11,20 \pm 10,66$ & $14,80 \pm 14,04$ & $10,40 \pm 13,76$ & $13,60 \pm 14,22$ & $6,20 \pm 6,87$ & $8,20 \pm 7,8$ & $8,40 \pm 10,71$ \\
64 & $7,60 \pm 6,66$ & $11,60 \pm 12,58$ & $8,60 \pm 11,32$ & $10,00 \pm 11,4$ & $4,00 \pm 6,16$ & $4,20 \pm 7,82$ & $5,60 \pm 7,27$ \\
72 & $5,00 \pm 5,15$ & $8,80 \pm 9,04$ & $5,40 \pm 8,36$ & $7,00 \pm 10,86$ & $3,40 \pm 6,07$ & $3,40 \pm 6,54$ & $4,00 \pm 6,82$ \\
88 & $3,00 \pm 4,12$ & $5,80 \pm 8,26$ & $4,60 \pm 6,62$ & $2,20 \pm 3,5$ & $2,60 \pm 5,27$ & $3,00 \pm 6,16$ & $2,80 \pm 6,26$ \\
96 & $1,60 \pm 3,58$ & $3,40 \pm 7,6$ & $2,8 \pm 4,15$ & $0,40 \pm 0,9$ & $2,00 \pm 4,47$ & $2,80 \pm 6,26$ & $2,40 \pm 5,37$ \\
112 & $0,80 \pm 1,79$ & $2,40 \pm 5,37$ & $2,00 \pm 3,47$ & $0,20 \pm 0,45$ & 0 & $2,40 \pm 5,37$ & $1,20 \pm 2,68$ \\
120 & 0 & $1,80 \pm 4,03$ & $1,00 \pm 2,24$ & 0 & 0 & $0,80 \pm 1,79$ & $0,80 \pm 1,79$ \\
136 & 0 & $1,00 \pm 2,24$ & $0,80 \pm 1,79$ & 0 & 0 & $0,40 \pm 0,89$ & $0,60 \pm 1,34$ \\
144 & 0 & $0,40 \pm 0,9$ & $0,60 \pm 1,34$ & 0 & 0 & $0,40 \pm 0,89$ & $0,60 \pm 1,34$ \\
160 & 0 & 0 & 0 & 0 & 0 & 0 & 0 \\
\hline
\end{tabular}

$\mathrm{MS} 1=$ pengencer tris kuning telur + madu Sumbawa $1 \%$; MS2 $=$ pengencer tris kuning telur + madu Sumbawa 2\%; MS3= pengencer tris kuning telur + madu Sumbawa 3\%; MO1= pengencer tris kuning telur + madu olahan $1 \%$; MO2= pengencer tris kuning telur + madu olahan $2 \%$; MO3= pengencer tris kuning telur + madu olahan 3\%; K= pengencer tris kuning telur + glukosa (kontrol), jam ke-16, 24, 40 , dst. $=$ pengamatan setelah penyimpanan, jam ke-0 $=$ pengamatan sebelum dibagi menjadi 7 kelompok; ulangan $=5$.

Pengamatan terhadap viabilitas pada jam ke-24, jam ke-48, dan jam ke-72 dalam pengencer madu Sumbawa tertinggi pada konsentrasi $2 \%$ memiliki rerata masing-masing $21,8 \pm 14,06 \%, 14,8 \pm 14,04 \%$, dan $8,8 \pm 9,04$ $\%$ dengan lama kemampuan hidup selama 144 jam. Rerata viabilitas madu kemasan pada jam ke-24, jam ke-48, dan jam ke-72 tertinggi pada konsentrasi $1 \%$ yaitu secara berturut-turut sebesar $25 \pm 15,6 \%, 13,6 \pm 14,22 \%$, dan $7 \pm$ $10,86 \%$ dengan lama kemampuan hidup selama 112 jam.

\section{DISKUSI}

Hasil pengamatan jam ke-24 pada pengencer madu Sumbawa tertinggi pada konsentrasi $2 \%$ yang memiliki rerata motilitas sebesar $9 \pm 8,94 \%$ dengan lama kemampuan motilitas tertinggi yaitu selama 64 jam. Pada pengencer madu kemasan tertinggi pada konsentrasi $1 \%$ yang memiliki rerata motilitas sebesar $14 \pm 9,62 \%$ dengan lama kemampuan motilitas tertinggi kedua yaitu selama 48 jam.

Faktor yang mempengaruhi motilitas spermatozoa antara lain umur spermatozoa, 
tingkat maturasi, morfologi dan sifat-sifat biokimia, faktor yang menyangkut pengadaan energi misalnya transport melalui membran spermatozoa, sumber nutrisi fruktosa, kontraksi otot polos pada duktus-duktus di saluran reproduksi, faktor biofisika, viskositas, $\mathrm{pH}$, temperatur, dan komposisi ion dalam media yang ada disekelilingnya (Afifatunnisa, 2013). Rendahnya kualitas spermatozoa asal kauda epididimis setelah pengolahan diduga karena rusaknya membran plasma sel karena tidak seperti spermatozoa hasil ejakulasi, membran plasma spermatozoa asal kauda epididimis tidak mendapat glikoprotein dari kelenjar vesikularis yang terdapat pada plasma semen (Rizal dan Herdis, 2005). Perlu adanya penambahan plasma semen yang kemudian diencerkan dengan pengencer yang tepat untuk dapat memberikan perlindungan optimal terhadap membran plasma spermatozoa hasil koleksi dari kauda epididimis pada penyimpanan suhu $3-5{ }^{\circ} \mathrm{C}$ (Rizal dan Herdis, 2006), sehingga dapat diketahui bahwa tingkat maturasi spermatozoa berpengaruh terhadap tingkat motilitasnya.

Berdasarkan hasil pemeriksaan mikroskopis motilitas dan viabilitas pada 24 jam spermatozoa dalam pengencer yang ditambah madu Sumbawa memiliki rata-rata motilitas dan viabilitas berturut-turut $6,3 \%$ dan $20,3 \%$ sedangkan pada pengencer yang ditambah madu kemasan memiliki rata-rata motilitas dan viabilitas berturut-turut $6,3 \%$ dan $18,3 \%$. Rata-rata kedua spermatozoa yang ditambah madu pada pengencer ini lebih tinggi dibandingkan dengan rata-rata pengencer kontrol yang tidak ditambah madu yakni rata-rata motilitas dan viabilitas secara berurutan adalah $3 \%$ dan $12.8 \%$. Daya hidup spermatozoa dapat dipengaruhi oleh motilitas, derajat keasaman atau $\mathrm{pH}$, dan kerusakan membran plasma (Dwitarizki et al., 2015).

Madu adalah pemanis alami yang berasal dari nectar (Ball, 2007). Kandungan utama madu yaitu senyawa karbohidrat seperti gula fruktosa (41\%), glukosa (35\%), sukrosa $(1,9 \%)$, dan dekstrin karbohidrat. Komposisi spesifik madu tergantung pada bunga yang tersedia untuk lebah yang menghasilkan madu tersebut (Bogdanov et al., 2008).
Beberapa keunggulan dari madu yaitu dapat menjadi pengganti gula, sumber vitamin dan mineral umumnya vitamin $\mathrm{C}$, kalsium, dan zat besi, sumber antioksidan yang dapat meminimalisir pengaruh buruk radikal bebas, dan mengandung zat antibiotik yang dapat mencegah pertumbuhan bakteri tertentu karena memproduksi enzim hydrogen peroksida (Nadhilla, 2014).

Pada pemeriksaan kadar vitamin $\mathrm{C}$ di Laboratorium Uji Fakultas Teknologi Pertanian UGM didapatkan hasil madu Sumbawa 12,49 $\mathrm{mg} / 100 \mathrm{~g}-13,31 \mathrm{mg} / 100 \mathrm{~g}$ sedangkan madu olahan didapatkan hasil 18,42 mg/100 g - 19,64 $\mathrm{mg} / 100$ g. Hasil tersebut menunjukkan bahwa kadar vitamin $\mathrm{C}$ pada madu kemasan lebih tinggi dari madu Sumbawa.

Karbohidrat dalam madu yang utama merupakan monosakarida, diantaranya yaitu fruktosa, glukosa, dan sukrosa (Ball, 2010) dan dalam pengencer, gula sederhana digunakan untuk menyediakan substrat energi bagi spermatozoa (Noakes et al., 2009). Sehingga, hasil penelitian tidak berpengaruh secara signifikan atau menghasilkan efek yang sama seperti kontrol karena pada madu terdapat gula sederhana yang dapat digunakan sebagai sumber energi dan dapat digunakan sebagai pengganti glukosa. Vitamin $\mathrm{C}$ atau asam askorbat merupakan salah satu antioksidan yang mempunyai kemampuan menguatkan kestabilan jaringan pelindung plasma terhadap peroksida lipid sehingga dapat memutus reaksi radikal bebas (Suryohudoyo, 2000). Penambahan vitamin $\mathrm{C}$ di dalam pengencer harus memperhatikan perubahan $\mathrm{pH}$ yang terjadi karena vitamin $\mathrm{C}$ bersifat asam (Rizal dan Herdis, 2010). Hasil analisis statistika pada motilitas dan viabilitas menunjukkan tidak adanya perbedaan yang signifikan antar pengencer yang berarti menunjukkan bahwa kadar vitamin $\mathrm{C}$ pada kedua jenis madu masih kurang efektif untuk mempertahankan kestabilan membran spermatozoa dan madu dalam pengencer spermatozoa dapat digunakan tetapi tidak dapat menghasilkan kualitas spermatozoa yang lebih baik. 


\section{KESIMPULAN}

Penggunaan madu Sumbawa dan madu kemasan dalam pengencer spermatozoa epididimis domba pada penyimpanan suhu refrigerator tidak berpengaruh terhadap motilitas dan viabilitas spermatozoa.

\section{DAFTAR PUSTAKA}

Afifatunnisa. 2013. Pengaruh Lama Waktu Kematian terhadap Kemampuan Motilitas Spermatozoa testis Hewan Coba Post Mortem yang Diperiksa pada Suhu Kamar dan Dingin. Thesis. Fakultas Kedokteran Universitas Diponegoro. Semarang.

Ball DW. 2007. The chemical composition of honey. J Chem Educ. 84:1643-6.

Bogdanov S, Jurendic T, Sieber R, Gallmann P. 2008. Honey for nutrition and health: a review. J Am Coll Nutr. 27: 677-89.

Dwitarizki ND, Ismaya, Asmarawati W. 2015. Pengaruh pengenceran spermatozoa dengan air kelapa dan aras kuning telur itik serta lama penyimpanan terhadap motilitas dan viabilitas spermatozoa domba Garut pada penyimpanan $5^{\circ} \mathrm{C}$. Buletin Peternakan 39: 149-56.

Hiemstra SJ, van der Lende T, Woelders $\mathrm{H}$. 2005. The potential of cryopreservation and reproductive technologies for animal genetic resources conservation strategies. Proc. of the Role of Biotechnology. Turin. Italy. $25-35$.

Mardhiati R, Marliyati SA, Martianto D, Madanijah S, Wibawan IWT. 2020. Karakteristik dan beberapa kandungan zat gizi pada lima sampel madu yang beredar di supermarket. Gizi Indon 43: 49-56.

Nadhilla NF. 2014. The activity of antibacterial agent of honey against Staphylococcus aureus. J Majority 3: 94-101.
Noakes DE, Parkinson TJ, England GCW. 2009. Reproduksi dan Obstetri Veteriner diterjemahkan oleh Aris Junaidi. Gadjah Mada University Press. Yogyakarta.

Rizal M, Herdis. 2005. Daya Hidup Spermatozoa Epididimis Domba Garut yang Dikriopreservasi Menggunakan Modifikasi Pengencer Tris. Hayati 12: 61-6.

Rizal M, Herdis. 2010. Peranan Antioksidan dalam Meningkatkan Kualitas Semen Beku. Wartzoa 20: 139-45.

Saepudin R, Sutriyono S, Saputra RO. 2014. Kualitas Madu yang Beredar di Kota Bengkulu Berdasarkan Penilaian Konsumen dan Uji Secara Empirik. J Sain Peternakan Indonesia 9: 30-40.

Surachman M, Herdis H, Setiadi MA, Rizal M. 2006. Kriopreservasi spermatozoa epididimis domba menggunakan pengencer berbasis Lesitin. J. Indon Trop Anim Agric. 31: 83-9.

Suryohudoyo P. 2000. Oksidan, Antioksidan, dan Radikal Bebas Dalam Kapita Selekta Ilmu Kedokteran Molekuler. Suryohudoyono P (ed) CV Sagung Seto. Jakarta. 31-47.

Wineri E, Rasyid R, Alioes Y. 2014. Perbandingan Daya Hambat Madu Alami dengan Madu Kemasan secara In Vitro terhadap Streptococcus beta hemoliticus Group A sebagai Penyebab Faringitis. Jurnal Kesehatan Andalas 3: 376-80.

Zulhawa DJ, Maryani M, Dewi NH. 2014. Daya Hambat Madu Sumbawa terhadap pertumbuhan Staphylococcus aureus Isolat Infeksi Luka Operasi. Biofarmasi 12: 40. 